\title{
Changes in Gender Stereotypes of Girl Characters in 20th and 21st-Century Croatian Children's Novels
}

\author{
Kristina Riman and Svetlana Stojanović
}

\begin{abstract}
Throughout the history of the Croatian education system, socialization of the child frequently implied learning about gender stereotypes. The main goal of this work is to investigate if gender stereotypes of girls in Croatian children's novels have changed from the beginning of the 20th century to the most contemporary novels. For that purpose, content analysis was performed on seven Croatian novels selected on the bases of their popularity, inclusion in school reading requirement lists and preliminary analysis of the centrality of gender roles in analyzed texts.

In the introductory part, some specific features of Croatian children's literature are listed with a special emphasis on the Croatian children's novel. Subsequently, gender stereotypes in early childhood development and research on gender stereotypes are discussed. In the second part of the article, we analyses the characterization of girls in the selected children's novels. Analysis indicates that gender stereotypes and counter-stereotypes are present in all novels. We found relatively more stereotypes in earlier novels and more counter-stereotypes in later novels. Also, stereotypes in earlier novels were delivered within educational context and purpose, while in later and most contemporary novels they are used as caricatures and for humorous effects.
\end{abstract}

Index Terms-Gender, stereotypes, Croatian children's novels, literature.

\section{INTRODUCTION}

When compared with literary production in other European countries, Croatian children's literature emerges relatively lately. Foundations for production and reception of Croatian children's literature are created during the 19th century. From the very beginning a notable effort to reduce pedagogical and educational elements in such literature can be observed as authors respected international trends in children's literature writing.

Children's literature is primarily determined by its recipients. Two basic criteria for the classification of children's literature are the age of assumed reader and a structure indicating literary genre [1]. The child's prose is the dominant literary genre, and it is made up of two types; a story and a novel [2]. The Croatian child's novel can be defined as a branched, complex and layered fictitious or realistic story of a child's life experiences with actors belonging to relatively homogeneous age group (usually around ten years old). A story is usually based on a specific child's experience of the world and their actions that, in unison, form a psychological

Manuscript received July 21, 2018; revised October 8, 2018.

Kristina Riman is with the Juraj Dobrila University of Pula, Zagrebačka 30, 52100, Pula, Croatia (e-mail: kriman@unipu.hr).

Svetlana Stojanović is with the Cerebral Palsy Association of the Istrian County, Gajeva 3, 52100 Pula, Croatia (e-mail: ucpiz.pu@gmail.com). and ethically profiled characters. It can also be a life story about a young individual in a specific time and social environment, usually classified within a context of realism in children's literature.

Novels that adhere to the principles of literary realism movement, especially examples of realism in children's literature [3] offer opportunities for observing socially relevant phenomena such as gender roles and stereotypes in the specific time and social environments. Therefore, elements of literary realism were considered for inclusion of novel in this analysis. Novels were also selected on the bases of their popularity, inclusion in school reading requirement lists and preliminary analysis of the centrality of gender roles in a novel. The analysis focused on the characterization of young girls, their thoughts and actions, environmental influences, gender stereotypes and the interplay of feminine and masculine characteristics in descriptions of the selected characters. To analyze possible changes in gender stereotypes over time, selected novels ranged from the early 20th century to the most contemporary published novels. Seven novels from six Croatian authors were selected (original title in brackets): The Golden Days (Zlatni danci) by Jagoda Truhelka, The Sparkle (Iskrica) by Mate Lovrak, You Lie, Melita (Lažeš, Melita) by Ivan Kušan, A Thief Lullaby (Lopovska uspavanka) by Pavao Pavličić, The Diary of Pauline P., (Dnevnik Pauline P.) and The Second Diary of Pauline P. (Drugi dnevnik Pauline P.) by Sanja Polak, and The Chattering Iva (Brbljava Iva) by Jelena Pervan.

\section{A. The Croatian Children's Novel: Historical Perspective}

The Strange Adventures of Hlapić the Apprentice, a novel written by Ivana Brlić-Mažuranić published in 1913 was for a long time considered as the first Croatian children's novel [2]-[6]. However, this was reconsidered in recent research indicating numerous Croatian children's novels dated from 19th and early 20th century [1]. There are three types of narrative organization of the Croatian children's novel until 1945: an adventure novel, a novel about the orphanage and a novel about children's societies. The first two types take on the perspective of an adult storyteller, and the child is not represented as an independent character. In early novels children are described as strongly dependent on adult characters and change toward children's relative independence can be noticed in novels from the third decade of the 20th century.

In the second half of the 20th century, childhood independence and association with the autonomous peer groups came to the fore, and the world of the child was separated from the world of adults. In the last century, during the sixties, stereotypes of an innocent and intuitive child, 
close to nature and fantasy, but also radically different and better than adults, together with stereotypical elements of fantasy as a motivational structure, enter into the center of interest of Croatian children's literature. At the end of the 20th century and the beginning of the 21 st century, thematic and age-related changes are evident, with an increase in publication of novels, structurally separated from children's themes and entering adolescent literature [7].

The novel about childhood prevails in Croatian children's literature. It is a novel about the life and the pursuits of children in the real world. It has clear determinants related to the description of characters, environment and circumstances of children's actions. Realism is emphasized as the boys and girls are shown in real situations and environments. The children described in the novel are usually about ten years old and belong to different social classes. The heroes and heroines of these novels are most often free characters, memorable, resourceful, lovable members of ordinary children's groups who handle every day and extraordinary tasks and problems.

According to Hans Robert Jauss's Reception theory, cultural codes and conventions particular to a specific time in history are essential in the interpretation of novels as perceived by the intended reader. In children's literature emphasis is on the children's horizon of expectations in a given time and place. In line with societal changes, intended readers are also changing. The theme-motive plan of recent and contemporary children's literature can be divided into three basic units: A) representation of the contemporary motives in a new, creative way, B) emerging new themes related to the urban environment and the world of technology, and finally, C) the taboo motives including narcotics, sexuality, sexual exploitation, rape, homosexuality, violence, death, illness, religion, ecology - nuclear disaster, homelessness, divorce, punishment and revenge [5].

Taboo themes entered the Croatian children's literature in the second half of the 20th century during the 60's, increased during the 70's and 80's and in 90's had its peak. It was assumed that such topics attract readers audience, and help children mature and grow. Also, apart from helping children, it was also assumed that including these topics helped parents recognize and overcome problem situations in their own lives [8]. Certain children characteristics were differently valorized in different historical periods burdened with different ideological assumptions. Conforming with or opposing to the stereotype came to the center stage of an increased number of literary publications and the gender stereotypes became prominent in the interpretation of the positive and negative traits of the child's character [9].

\section{B. Gender Stereotypes and Children's Development}

To understand gender stereotypes, one should keep in mind the difference between sex and gender. The sex of a child is determined by biological and physical differences, and 'gender' refers to psychological, sociological and cultural components including certain patterns of behavior and roles that have been culturally defined as typical for 'males' or 'females' [10]. Gender identity develops during childhood when a child becomes aware of gender categories and comes to a conclusion about its appropriate gender, while adoption of a gender role implies the assumption of attributes culturally assigned to males or females. In most cultures, even three-year-old know their gender identity and easily learn expectations about behavior and appearance that is assumed appropriate for boys and girls [11].

Children in most countries are traditionally early exposed to gender-appropriate rearing practices; they early adopt differences between male and female gender thus building appropriate gender stereotypes [12]. Gender stereotypes are defined as widespread beliefs about characteristics that are considered appropriate for men and women, while gender roles are defined as a reflection of these stereotypes in everyday behavior [13]. In addition to personality traits characteristic of men and women [14], there are other gender stereotypes that include body characteristics (e.g. men are tall, strong and tough, and women are gentle, delicate and charming), occupations (truck driver, insurance agent and chemist for men; elementary school teacher, secretary, nurse, good at caring for children and decorating a house for women), etc. [15].

Each culture or community promotes certain traits, patterns of behavior, values, and interests while condemning others thus directing individuals to the desired pattern. Gender-based knowledge and behavior sometimes are passed on to children by direct teaching [16], and on other occasions are implicitly modelled in everyday ordinary situations and interactions. The family is the first place where children meet with the role of a mother, father, brother, sister, and later they find out about other roles (extended family, neighbors, friends, etc.). In these situations, through direct experience, they gain knowledge of the existence, content and meaning of female and male roles. This cognitive knowledge affects the reception of experiences outside the family [17]. Through play materials and social interaction, family or parents encourage: “...assertiveness, research, engagement in the physical world and emotional control for boys, and imitation, reliance on others, and emotional sensitivity for girls. These experiences, in turn, give small children the wealth of characters to create a picture of the world that emphasizes stereotypical gender differences." [12].

Apart from the family, strong stereotypical patterns are imposed on children in the school, through behaviors of teachers and professors, but also in peer groups [18]. Media, toys, picture books, books, and animated films also maintain existing stereotypes when portraying male-female relationships and characteristics.

\section{Gender Stereotypes in Picture Books and School Reading Requirement Lists}

Gender differences and perspectives in children's books are in focus of the large body of contemporary research. One of the first attempts to investigate this topic was carried out by Weitzman, Eifler, Hokada and Ross [19] focusing on the period between 1930 and 1972. Results indicated that, when compared to male characters, leading female characters were much less present in the analyzed material. Women were more often represented through stereotypes: as subordinates, passive and attached to the house, while men are shown as active participants outside the home. In a later study conducted by Williams, Vernon, Williams, and Malecha [20] 
for the period 1980 to 1987 , results indicated that women in the picture books were portrayed as more active, that is, they more often assumed more masculine role, while the male characters were still displayed in stereotypically male roles. Usually, only the main female characters were in the nonstereotyped role, while the secondary female characters were still stereotyped.

In the 2006 research Hamilton, Anderson, Broaddus and Young [21] found that there has been no further increase in the frequency of the appearance of female characters in children's literature. Children's books and picture books contain twice as many male characters in main and secondary roles. Mostly male characters are featured on cover pages and illustrations. The girls are depicted as passive, naive, sweet and addictive, while boys are powerful, capable and adventurous. Mothers are most often described as doing various housework such as cooking lunch, serving meals, washing clothes, cleaning the house, while fathers usually garden or repair something, mostly outside the house. Fathers in-house activities are usually described as resting, reading newspapers or watching TV. Also, fathers are more visible in-game activities, more often with sons while mothers usually engage in emotional relationships.

In Croatia Baranović, Doolan and Jugović conducted a study on gender sensitivity in textbooks for primary education [22]. The study showed that women more often than men appear as authors of textbooks. However, it turned out that authors of textbooks for lower grades are exclusively women, while men only author textbooks for higher grades of elementary school. It is interpreted as an example of stereotypical thinking that women are more than men associated with younger children. Also, research has shown that men dominate as authors of articles and contributions in textbooks. Male characters appear more frequently than female in textbooks with literary excerpts.

Female characters in textbooks with literary excerpts usually appear as teachers, schoolgirls, housewives, athletes, princesses, nurses, lawyers, and villagers. Male characters appear as princes, teachers, entertainers, writers, journalists, leaders, military officials, craftsmen and policeman. Also, males appear as doctors, and women as nurses, suggesting to students that men are in higher positions in the professional hierarchy. By observing the family role of characters, it can be concluded that female characters often appear in the role of a devoted mother and a housewife, much more often than male characters as fathers, again confirming the stereotype that women are more associated with family and home. Textbooks with literary excerpts also focus more attention on the roles of sons rather than on the roles of daughters. Authors conclude that Croatian textbooks are written from a male perspective and that they promote a patriarchal image of gender identities dominated by superior men.

\section{GENDER STEREOTYPES IN OLDER AND CONTEMPORARY CROATIAN CHILDREN'S NOVELS}

Previous research identified numerous examples of gender stereotyping in different Croatian literary sources that negatively reflect on the role of girls and woman, even suggesting the promotion of the patriarchal image of gender identities. For that reason, the most noticeable change in gender stereotyping over time might be prominent in novels with girls in the roles of main characters. Novels with elements of realism in which girls have a perceptible role have been chosen for analysis. By analyzing their thoughts and actions, as well as the environment in which their characters were placed, we selected those parts of the text where some gender stereotypes or counter-stereotypes were identified. For comparative analysis novels from different literary and historical periods were selected, allowing for investigation of changes in descriptions of girl's characters, the relationship between their feminine and masculine attributes, and changes in stereotypes or counter-stereotypes over their personal development and over historical periods when novels were published.

\section{A. Anica}

In the rich opus of Jagoda Truhelka most prominent is a trilogy about childhood: "The Golden Days" (Zlatni danci; 1919). The main female figure, Anica, is described as a typical nine years old girl who likes to play with her dolls, talk to friends, fantasize and to dream. She is emotional, likes music [23], but sometimes she is angry and feels that she needs to fight for her right to be autonomous and appreciated. She usually cries in situations when she realizes that someone has been neglected. When her teacher complains to her about the difficult life she has, Anica listens and cries of compassion and sorrow for someone else's misfortune [23].

Though she is fond of day-dreaming, fantasizing and of long-term observation of nature, she is also responsible and entrusted with tasks such as looking after her brothers. Anica's character is portrayed with typical feminine traits that are recognizable in her empathy, altruism, full dedication to others, awareness and understanding of their feelings, gentleness, kindness, and attention.

When maid Christina has become sick, Anica acts with a sacrificial, empathic and voluntary help [23]. When his brother Ćiro was injured, Anica was constantly worried about him. She is giving him a drink and offers him her sweets, and at the same time, as the oldest child, she helps to raise a younger brother [23].

Anica is mainly occupied with the home, housework, and women's duties. For her actions she requires the approval from significant others. However, her spirit strives for something else. Her brothers play carefree, while Anica, doing her daily job of knitting and looking after her brothers, often thinks about how she wants to be a boy [24].

Anica, as the oldest female child, feels an injustice in patterns of obligations that were conditioned only by the society. Apart from her internal struggles against gender stereotypes, she fails in any particular rebellion.

“- Oh, mummy (...) That is an injustice! Why is that so?

Then the mother replied:

- Because they are boys, and you are a girl.

- But I do not see any justice in that; this is very wrong to me - Anica continued. - Because I'm a female, I'm not only learning in the school and reading books as they do. Sometimes I do this even better, but also, I am doing housekeeping, help with this and that, and God knows what 
another job you will still give me to do.

-And what can you do? - Mother sighted - This is our destiny. At all times, the girl had to, first and foremost, be skilled in all kinds of housework, and this also includes sewing and crocheting." [23].

Anica's character can be interpreted in the context of Truhelka's biographical but also historical facts that are precisely related to her contribution to feminist literature or a woman's writing of that time [25]. At the end of the 19th century, the first wave of the feminist movement to change the position of women in society started. The issue of women in Croatia was addressed with education reform. At the end of the 19th century, girls could be educated for certain occupations by provisions of the education reform. As a teacher, intellectual and writer, Jagoda Truhelka participated in cultural life. With her literary and pedagogical work, she led new ideas about the position of women in society.

In her literary works and articles, Truhelka advocates equality for women, believing that women must be free and provided with proper education in order to be able to make informed choices about their life. That is why Truhelka considers feminist agenda while discussing the dominant roles of the genders in the society. She considers the social idea of woman's position in society at the same time pondering and problematizing ideas about the children education and the concept of a child's inborn identity. Truhelka's autobiographical features are also recognized in Anica's character, especially in her situation and upbringing in the family, but also in the spontaneous struggle for women's equality [5]. Anica thinks about her family identity, recognizing social and family differences in the perception of children with regard to her gender identity. Such thinking encourages uneven allocation of tasks and obligations with respect to the gender identity that she proclaims as unjust [9].

\section{B. Iskrica}

Mate Lovrak was a prolific Croatian author active in the first half and middle of the 20th century. In his novel "Iskrica" (1959), he describes the girl who lives with her parents in the big city. She is nine years old and is exclusively portrayed in the family context. At the very beginning of the novel, she was described as a quiet, obedient, regular and responsible girl, fully committed to doing school assignments. The first deviation from the stereotypical view and thinking attributed to girls relates to her choice of profession.

"She finished school classes with great success. There is no better schoolgirl in her elementary school. She will attend the high school, and she will become a professor at the university, or maybe even a doctor. An engineer. Or a woman judge!" [26].

Iskrica shows herself as particularly attentive and aware of the feelings of others when she meets the girl Nadja. Nadja's mother died, and she was saddened by such an event. She also shows itself as generous when she says that she wants to choose a job to work solely for the benefit of others [26].

Iskrica lives in a traditional patriarchal family where the father is the chief custodian of the family. Although living in a family where a man is considered the head of a home and with strict gender division of jobs, Iskrica at times expresses her resistance to such attitude. She expresses her dissatisfaction with the fact that despite her father being a well-educated man, he still expects of a woman only to do cooking and housework.

"Dad's out of date. Futilely he read so many books, watched movies and went to theatre, when he thinks that woman is destined only to cook!" [26].

Iskrica is portrayed as a weak girl conditioned and formatted in accordance with stereotypical gender role. She is described as calm, obedient, responsible, empathic, compassionate, and fully attached to parents. Usually, she is in the shadow of her parents, especially the father who supervises and directs all her actions [26], as well as her acquaintances with friends [26]. Iskrica expresses her feelings in situations when she takes care of others [26]. Her negative attitude towards the stereotype roles of society is evident in sporadic protesting against the gender stereotypes.

Mato Lovrak is well-known for his novels in which the child's independence is interwoven with play. Peer groups become the fundamental modelling narrative matrix of Croatian children's literature of the second half of the 20th century [7]. Lovrak's male characters are manifested in collectivism and are superior to adults. However, his female characters are weak, and they depend on a man. Therefore, most of his novels include stereotypes about gender roles. Lovrak emphasized that his inspiration in the formation of characters was found in real school events, which he witnessed working many years in schools. He also mentions that he had less opportunity to study the psychology of girls because he worked as a teacher in a male school [27]. In the formation of the characters, he was inspired by the members of his family, and he created Iskrica with reference to characteristics of his daughter.

\section{Melita}

Ivan Kušan started his writing career in the mid-twentieth century. The novel "You lie, Melita" (Lažeš, Melita; 1965) speaks of a girl who is constantly lying, while her parents try to teach her about the importance of truth. Melita lives with her parents and brother Nenad. She is described as a lively twelve-year-old girl who needs to be active and take the initiative: "She has never felt so grown up, and she has never been so proud yet. She needs to look after Nenad and Dad." [28].

When Melita's mother leaves to visits a sick aunt, Nenad and Father decide to "cure" Melita from lying so that they take actions to recreate her fictious events. Melita becomes a passive observer of unexplained events in her environment and the passive recipient of male's plot [9]. Melita, confused from the unexpected effectuation of her fictitious tales, easy starts to cry and becomes irritable: "Melita sadly stared at her father, covering her face with her hands, screaming and running out of the room." [28].

On the other hand, Melita is described counter-stereotypically as a lively, active and ingenious girl who is inclined to take the initiative, acting as a family leader. In the first part of the book, Melita is characterized by typical masculine features. In the second part, she is pressed by unexpected situations orchestrated by her male family members and becomes a stereotyped girl: ashamed, confused, irritable and insecure. 
In most Kušan's novels, the main role is played by boys who are looking for adventures, and action games or who look for something unusual and mysterious in their environment. In this novel, Kušan puts the girl Melita in the center but burdens her with an inclination for lying, or 'illness of the imagination' as her parents call it. For the most of his writing, Kušan does not make significant differences between boys and girls, thus defining characters by traits, not by gender [8]. Positive and negative elements are evenly distributed in girls' and boys' characters, which is also evident in the characterization of Melita and her brother Nenad who also has a fair share of unflattering features.

\section{D. Štefa}

During the eighth decade of the 20th century, Pavao Pavličić writes children's crime and adventure novels. "The Thief's Lullaby" (Lopovska uspavanka; 1992) speaks about a group of children that solves mysteries and helps grownups in finding criminals. In the center of the action, there are three main figures: Braco, Tut and Hrvoje, and a girl side-figure called Štefa.

Stefa is described in the novel as an unusual female figure whose characteristics resemble a boy. She is not beautiful, but she is active, and with her ingenuity and courage she is accepted as equal in the boy's club [29].

The girl responds to the male nickname Stef.

"Her name is Štefa, - Hrvoje said. - But everyone calls her Stef.

And that was fine. Now it was clear what was unusual about this girl: not only is she untidy and neglected, but she also walked out of her knees like a man, and had a little swing in her shoulders, like a cowboy. Devilish woman" [29].

Štefa is, in every situation calm and shows no fear. She is extremely brave and sometimes acts as a leader. She is self-confident and superior to others. After Hrvoje's dad ordered them to wait at home while he was going to the police, Stefa engaged in physical conflict:

"Dubravko flopped and dropped the gun. Braco jumped from the chair at the same moment. Stefa stood in the workshop door and held in her hand the neck of the guitar, separated from the body." [29].

In the "Thief's Lullaby", the boys, Braco, Tut and Hrvoje, who usually solve crime mysteries, remain in the background and are overshadowed by the subsidiary character of Stefa. Štefa is characterized by typical masculine features such as activity, ingenuity, the absence of fear, and superiority. She is self-confident and equal to her male peers. The boys completely dependent on her, especially in the decisive moments when they were about to liberate master Fabris and confront the enemies.

Pavličić's children's novels belong to the crime novels genre. The action usually takes place around a group of boys, and girls are usually side figures. Pavličić follows the tradition in which the main characters are playful and adventure-loving boys. Girls in his novels play a secondary role. Štefa is a notable exception in his writing and most prominent example of gender counter-stereotype in children's novels.

\section{E. Paulina}

“The Diary of Paulina P." (Dnevnik Pauline P.; 2000) is the first children's literature novel by Sanja Polak. Paulina, a nine-year-old girl, keeps her diary describing school and family events from the beginning to the end of the school year. Paulina is described with a mixture of feminine and masculine traits. As a girl, she is extremely capricious, chattering, amorous, but also manipulative, and competitive. She is concerned about real problems in school such as writing assignments, choosing the best friend, quarrelling, sharing with friends, and discovering new friends. She worries about her looks, and she loves to buy nice clothes. In situations when she is not happy with herself, she easily starts to cry [30]. She is also on some occasions careful and devoted to others [30].

In the family, Paulina's mother performs stereotypical women's activities, and has a special room for ironing and sewing, while dad spends the most time in his workshop or the basement. On Sunday the mother is in charge of preparing lunch. When preparing Christmas cakes, Paulina's grandmother and mother quarrel, and the father regularly emphasize that this is a women's job.

Paulina is taking care of school obligations, socializes with friends, and she does not need to do home-related chores. However, gender stereotypes are present in the behavior of her aunt Renata (she regularly visited hairdressers, beauticians and pedicures), while her husband is a typical representative of mail gender counter-stereotype because he took over all household affairs:

"Uncle Joža was great. Always at home. He hanged the laundry on the balcony because the rope was too high for aunt Renata, vacuumed the house because aunt Renata was allergic to dust, wore full bags from the market because that was too heavy for aunt Renata, washed windows because aunt Renata was afraid of the heights. And every morning he made coffee because aunt Renata could not function at all before the first-morning coffee. Aunt Renata took care of herself. She visited hairdressers, beauticians, pedicures, private tailors, saunas and fitness centers. (...) This happened to Joža because he hanged the laundry and washed the windows instead of Renata. And I told him nicely that it was not a male's job. " [30].

Also, in the novel, there is a stereotype about the chattering women. Paulina is also described as a very talkative little girl.

"And I like to talk. And nobody wants to listen to me. (...) While silent, I felt unhappy, lonely and neglected" [31].

Paulina wants to be a good mother when she grows up, like her friend's mother Mirica, who, unlike her mother, is always hanging out with her kids and goes to the playgrounds:

"I've been thinking these days what I'm going to be. I thought and decided. I'll be just mom. After elementary school, I will enroll in a gymnasium for moms, and if I do well, I will also enroll in the parent's faculty. All I have to do is find out where those schools are, and which school subjects are taken into consideration for admission." [31].

In the novels, there are obvious attempts to depart from the typical stereotypes. Paulina's father says that men are not meant to do housework, but when mom does not manage to do it, he vacuums, cleans the dust in the house, and cleans the 
bathroom. On the other hand, Paulina's mother decides on family finances.

Paulina P. is described with typical feminine traits such as exaggerated emotionality, irritability, crying in crisis situations, but does not fit completely in the pattern of female gender stereotype. In her family, there is a division into male and female affairs. Paulina's mother performs stereotypical women's affairs, but she does not expect it from her daughter.

Sanja Polak describes Paulina growing up from nine years to puberty. The author states that the literary figure of Paulina was conceived after the birth of her daughter Pauline [32]. A character that is inspired by a real person, Paulina $\mathrm{P}$. represents a contemporary girl within the context of realistic problems and situations.

\section{F. Iva}

Young writer Jelena Pervan has published several books for children. The children's novel "The Chattering Iva" (Brbljava Iva; 2013) is also written in the form of a diary containing Iva's thoughts and everyday school and family activities.

The main character of the novel, nine-year-old Iva, writes a book. At the very beginning of the book, she describes her parents, a mother who is a dentist, a father who is a journalist and her friends. Iva is trying to choose a future profession, but in all considered jobs she finds problems and disadvantages. She also points out a non-stereotypical career choice for a woman:

"And me? I don't know what I should be when I grow up. I think I'll never be able to decide on a single job. There is nothing else left for me to be other than a politician. My dad says that they do no work and have a full box of money. I think this is an ideal job for me" [33].

Iva has orange hair and freckles on her nose and looks like Pipi Longstocking. She is forgetful and negligent. However, when she goes to an orphanage with her mother, she turns out to be extremely emotional, compassionate and ready to help [33].

When describing mother and father, Iva breaks stereotyped gender roles between men and women making fun out of inverse stereotypes. This is illustrated by situations in which the father routinely steals mother's makeup and wrinkle creams:

"Dad always says that women are created for creams and makeup, and men for practical things. When we are with friends, he always elaborates for hours how his soft skin is owed to nothing other than soap and cold water.

- Naturally beautiful - dad will say. But my dad is a liar, bigger than Pinocchio.

My dad is a real makeup artist. In the bathroom, there are more creams and shampoos for him than for mum and me together, and we're girls. Once I caught him as he smeared mother's cream for wrinkles on his cheeks. Natural beauty, sure!" [33].

All stereotypes are shown in a comic style. Sometimes they are described as reversed stereotypes, and sometimes they are used for humor.

"My dad says that nowadays it is a real art when a man knows how to fix things at home, so whenever dad changes a light-bulb, it is a SEN-ZA-TI-ON!" [33].
Diversity and a kind of uniqueness that is in complete opposition to the everyday life are the cornerstones of the literary publications of Jelena Pervan. Her novel has the stereotypical female expression of chattering embedded in the title. As Iva departs from typical feminine traits, description of other characters offers many opportunities to reverse the stereotypes or to laugh at them.

\section{INTEGRATION OF FINDINGS ACROSS ANALYSED NOVELS}

Analysis of selected literary examples indicates that at the very beginning of the 20th century, Croatian childhood novels clearly showed gender stereotypes presented as educative instructions for young girls and boys. While boys are depicted as active participants in various adventures, girls have mostly secondary roles, and they are shown mainly as passive observers of events. In the rare Croatian children's novels dating back to the 19th century, in which the main character is a girl, the expectations of the society are clear. Girls are focused on home and family, and they are expected to sustain the household. Although girls' characters express their fears of such expectations, their resistance to stereotypes is not strong enough, or the circumstances in which they live do not support a deviation from the usual and traditional ways of conduct.

The stereotypical representation of girls in a Croatian children's novels undergoes a transformation in the second half of the 20th century. This is the time when nonstereotyped characters that deviate from the prevailing patriarchal attitude are described. Only a small number of novels are still published in which the girl is the main character, but it is more likely to find novels where main girl character takes the initiative and courageously participates in the events.

In the 21 st century, Croatian children's literature further promoted non-stereotypical characterization of girls. They become active participants in the novel and, in certain situations, there are superior over their male peers. The novels depict family relations that deviate from the stereotypically partisan image of the society. Mothers leave the premises of the home and become family providers, and fathers are more often described within the family and a household context. This does not mean that gender stereotypes are not present in contemporary novels, but they are often used as humorous elements.

\section{CONCLUSION}

Gender stereotypes and counter-stereotypes are present in all selected novels. We found relatively more stereotypes in earlier novels and more counter-stereotypes in later novels. Also, stereotypes in earlier novels were delivered within educational context and purpose, while in later and most contemporary novels they are used as caricatures and for humorous effects.

Presented findings suggest that there are systematic shifts in the historical representations of girls' characters in Croatian children's literature. Earlier novels are heavily burdened with gender stereotypes, and more counter-stereotypes are found in later novels. Also, stereotypes in earlier novels were delivered 
with educational context and purpose, while in most contemporary novels they are used as caricatures and for humorous effects. Regarding age differences, the younger girls were usually depicted as expressing their dissatisfaction and disapproval, mainly due to the unfair division of labour and the restrictions they had, while adult female characters expressed acceptance of the circumstances in which they lived In more contemporary novels, girls no longer need to express their rebellion against the stereotypical roles and stereotypes are used as an exaggeration or as a humorous element.

If the portrayed image of girls and the presence of gender stereotypes in novels represent a picture of a society reflected in literature, we can conclude that we have made considerable progress in gender equality, at least as it is recorded in writings of Croatian children's literature over several generations of writers.

\section{REFERENCES}

[1] B. Majhut, "Treba li nam nova povijest hrvatske dječje književnosti?" Fluminensia, vol. 27, no. 1, pp. 189-202, July 2015.

[2] M. Crnković and D. Težak, "Povijest hrvatske dječje književnosti od početka do 1955," Godine. Zagreb: Znanje, 2002.

[3] R. Wald, "Realism in children's literature," Language Arts, vol. 52, no. 7, pp. 938-949, 1975.

[4] I. Zalar, "Dječji roman u hrvatskoj književnosti," Zagreb: Školska Knjiga, 1983.

[5] S. Hranjec, "Pregled hrvatske dječje književnosti," Zagreb: Školska Knjiga, 2006.

[6] M. Crnković, "Dječja književnost: Priručnik za studente i nastavnike," Zagreb: Školska Knjiga, 1990.

[7] M. Hameršak and D. Zima, "Uvod u dječju književnost," Zagreb: Leykam International, 2015

[8] "Tabu teme u književnosti za djecu i mladež," Zagreb: Knjižnice Grada Zagreba, 2002.

[9] D. Zima, "Kraći ljudi: Povijest dječjeg lika u hrvatskom dječjem romanu," Zagreb: Školska Knjiga, 2011.

[10] C. Declercq and D. Moreau, "Rađaju li se djeca kao dječaci i djevojčice - ili takvima postaju?" Djeca u Europi: Zajednička Publikacija Mreže Europskih Časopisa, vol. 4, no. 8, pp. 18-19, Oct. 2012.

[11] Z. Marović, "Ne smiješ plakati, ti si dječak," Dijete, Vrtić, Obitelj: Casopis za Odgoj i Naobrazbu Predškolske Djece Namijenjen Stručnjacima i Roditeljima, vol. 15, no. 58, pp. 18-23, Dec. 2009.

[12] L. E. Berk, "Dječja razvojna psihologija: prijevod 8," Jastrebarsko: Naklada Slap, 2015.

[13] R. D. Ashmore and F. K. Del Boca, "Sex stereotypes and implicit personality theory: Toward a cognitive-social psychological conceptualization," Sex Roles, vol. 5, pp. 219-248, 1979.

[14] D. L. Hamilton and T. K. Trolier, Stereotypes and Stereotyping: An Overview of the Cognitive Approach in Prejudice, Discrimination, and Racism, J. F. Dovidio and S. L. Gaertner, Eds. Orlando, FL: Academic Press, 1986.

[15] R. D. Ashmore, F. K. D. Boca, and A. J. Wohlers, Gender Stereotypes in the Social Psychology of Female-Male Relations, R. D. Ashmore and F. K. D. Boca, Eds. Orlando, FL: Academic Press, 1986.

[16] P. A. Katz, Gender Identity: Development and Consequences in the Social psYchology of Female-Male Relations, R. D. Ashmore and F. K. D. Boca Eds. Orlando, FL: Academic Press, 1986.

[17] B. Baranović, "Slika" žene u udžbenicima književnosti. Institut za društvena istraživanja u Zagrebu: Zagreb, 2000.

[18] J. Belamarić, "Ružičasto i plavo - rodno osviješten odgoj u vrtiću," Dijete, Vrtić, Obitelj: Časopis za Odgoj i Naobrazbu Predškolske Djece Namijenjen Stručnjacima i Roditeljima, vol.15 no. 58, pp.14-17, Dec. 2009.

[19] L. J. Weitzman, D. Eifler, E. Hokada, and C. Ross, "Sex-role socialization in picture books for preschool children," American Journal of Sociology, vol. 77, no. 6, pp. 1125-1150, May 1972.
[20] J. A. Williams, J. A. Vernon, J. C. Williams, and K. Malecha, "Sex role socialization in picture books: An update," Social Science Quarterly, vol. 68 , no. 1 , pp. $148-156$. Mar. 1987

[21] M. C. Hamilton, D. Anderson, M. Broaddus, and K. Young, "Gender stereotyping and under-representation of female characters in 200 popular children's picture books: A twenty-first century update, Sex Roles, vol. 55, no. 11-12, pp. 757-765, Dec. 2006.

[22] B. Baranović, K. Doolan, and I. Jugović, "Jesu li čitanke književnosti za osnovnoškolsko obrazovanje u Hrvatskoj rodno osjetljive?" Sociologija $i$ Prostor : Časopis za Istraživanje Prostornoga i Sociokulturnog Razvoja, vol. 48, no. 2(187), pp. 349-374, Dec. 2010.

[23] J. Truhelka, "Izabrana djela I. Zlatni danci (I)," Zagreb: Naša Djeca, pp. 11-159, 1995

[24] J. Truhelka, "Izabrana djela IV. Dusi domaćeg ognjišta," Zagreb: Naša Djeca, p. 154, 1995.

[25] V. Ž. Zebec, "Naša djeca jagode truhelke - poučavanje sudbinama ženskih likova," Libri et Liberi : Časopis za Istraživanje Dječje Književnosti i Kulture, vol. 4, no.1, pp. 27-43, Oct. 2015.

[26] M. Lovrak, "Iskrica," Zagreb: Mladost, pp. 10-77, 1964.

[27] M. Lovrak. O svojim književnim nadahnućima. [Online]. Available: https://www.youtube.com/watch?v=IcB-9JJE7Ow

[28] I. Kušan, "Lažeš, Melita," Zagreb: Znanje, pp. 29-94, 2012.

[29] P. Pavličić, "Lopovska uspavanka," Zagreb: Znanje, pp. 33-136, 1992.

[30] S. Polak, "Dnevnik Pauline P," Zagreb: Mozaik Knjiga, pp. 18-157, 2010.

[31] S. Polak, "Drugi dnevnik Pauline P," Zagreb: Mozaik Knjiga, pp. $92-139,2010$

[32] T. Borić. Interview: Sanja Polak 'Lijepa riječ lektira kod nas je uvijek nešto negativno, to treba mijenjati', Nacional. [Online]. Available http://www.nacional.hr/interview-sanja-polak-lijepa-rijec-lektira-kodnas-je-uvijek-nesto-negativno-to-treba-mijenjati/

[33] J. Pervan, "Brbljava Iva," Zagreb: Biblioteka Mala, pp. 7-36, 2013.

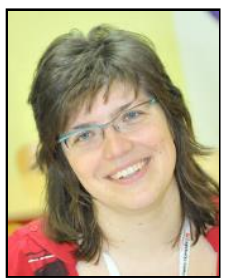

Kristina Riman is a Croatian teacher and researcher in the field of philology. She graduated Croatian language and literature study program at the Faculty of Humanities and Social Sciences, University of Rijeka, Croatia. She also received postgraduate M.Phil. degree in Croatian literature at the University of Zagreb, Croatia and a PhD degree at the University of Rijeka, Croatia.

Currently, she is employed as an assistant professo at the Juraj Dobrila University of Pula, Croatia where she teaches subjects related to children's literature and media culture. Previously she was employed at the high school gymnasium Andrija Mohorovičić, Rijeka, Croatia as a teacher of Croatian language.

Dr. Riman is a member of the Croatian Association of Researches in Children's Literature, and a member of the University of Ljubljana Global Alumni and Associates Network. She authored or co-authored five books, eight book chapters, nine articles in scientific and professional journals and 12 chapters in conference proceedings. Her professional interests include research in children's literature, travel writings and cross-cultural topics related to Croatian and Slovenian literature and history.

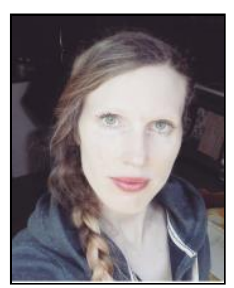

Svetlana Stojanović is currently in charge of programs of Cerebral Palsy Association of the Istrian County, Croatia where she coordinates personal assistants that support children who suffer from severe physical or mental disabilities. Previously she worked as a program assistant for the Association for development of audio-visual media arts "Metamedij". She received univ. bacc. philol. croat. et ital. degree from the Croatian and Italian Language and Literature Study Program at the Juraj Dobrila University of Pula, Croatia.

Ms. Stojanović is engaged in numerous volunteering activities. She also has experience in psychosocial support for children through pet-therapy association "Indeficienter". Currently, she is attending NTC workshops to become assistant in programs for supporting logical and associative thinking through play oriented cognitive and physical activities. 